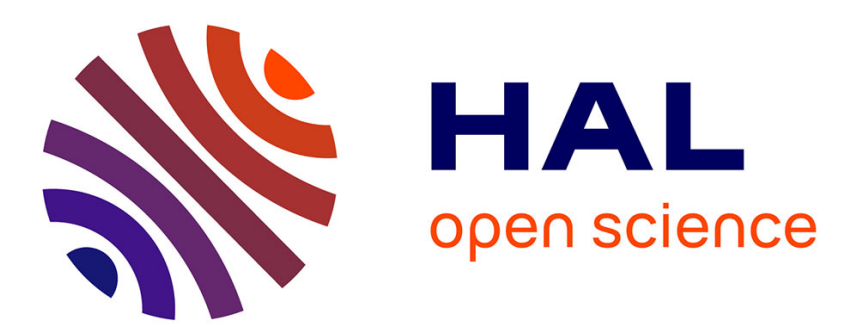

\title{
Engineering nitrile hydratase activity into a cysteine protease by a single mutation
}

\author{
E. Dufour, A.C. Storer, R. Menard
}

\section{To cite this version:}

E. Dufour, A.C. Storer, R. Menard. Engineering nitrile hydratase activity into a cysteine protease by a single mutation. Biochemistry, 1995, 34 (50), pp.16382-16388. hal-02708812

\section{HAL Id: hal-02708812 \\ https://hal.inrae.fr/hal-02708812}

Submitted on 1 Jun 2020

HAL is a multi-disciplinary open access archive for the deposit and dissemination of scientific research documents, whether they are published or not. The documents may come from teaching and research institutions in France or abroad, or from public or private research centers.
L'archive ouverte pluridisciplinaire HAL, est destinée au dépôt et à la diffusion de documents scientifiques de niveau recherche, publiés ou non, émanant des établissements d'enseignement et de recherche français ou étrangers, des laboratoires publics ou privés. 
Engineering Nitrile Hydratase Activity into a Cysteine Protease by a Single Mutation $^{\dagger}$

\author{
Éric Dufour, ${ }^{\ddagger}$ Andrew C. Storer, and Robert Ménard* \\ Biotechnology Research Institute, National Research Council of Canada, 6100 Avenue Royalmount, \\ Montréal, Québec, H4P 2R2, Canada
}

Received August 10, 1995; Revised Manuscript Received October 10, $1995^{\otimes}$

\begin{abstract}
A peptide nitrile hydratase activity has been engineered into the cysteine protease papain by a single carefully selected mutation at the active site of the enzyme. The papain variant Gln19Glu hydrolyzes the substrate MeOCO-PheAla-CN to the corresponding amide with a $k_{\text {cat }} / K_{\mathrm{M}}$ value of $1.15 \times$ $10^{3} \mathrm{M}^{-1} \mathrm{~s}^{-1}$. The reaction leads to an accumulation of the corresponding amide, which is then further hydrolyzed to the acid by the natural amidase activity of the enzyme. The pH-dependency of the nitrile hydratase activity of Gln19Glu supports the involvement of the acid form of the Glu 19 residue in the reaction. The wild type enzyme displays very weak nitrile hydratase activity, and the introduction of a glutamic acid residue in the oxyanion hole of papain causes the $k_{\mathrm{cat}}$ at $\mathrm{pH} 5$ to increase by a factor of at least $4 \times 10^{5}$. Peptide nitriles react with cysteine proteases to form thioimidates, and the role of the glutamic acid residue introduced at position 19 in the Gin19Glu enzyme is to participate in the acidcatalyzed hydrolysis of the thioimidate to the amide by the provision of a proton to form the more reactive protonated thioimidate. This dramatically decreases the energy barrier for the hydrolysis of the thioimidate, as shown by the impressive increase in $k_{\text {cat }}$. The success of the rational approach undertaken is a consequence of the level of understanding of the basic catalytic properties of cysteine proteases of the papain family.
\end{abstract}

The term "protein engineering" has evolved to represent the complementary application of diverse technologies to the design, construction, or modification of proteins. Applications of protein engineering can be divided in two main areas: its use as a means of interpretating and understanding the properties of proteins at the molecular level through the establishment of structure-activity relationships and its application to the rational design and production of proteins with new or modified properties. Since the term protein engineering was popularized more than a decade ago (Ulmer, 1983) the contributions of individual or groups of amino acids to numerous protein properties (e.g., enzyme specificity and catalysis, protein stability, folding pathways) have been extensively investigated (Fersht \& Winter, 1992). Protein engineering has also been used to modify proteins with the goal of conferring on them improved properties useful for specific applications. So far the greatest successes in this direction involved domain swapping, alteration of substrate specificity, and improved stability in unusual environments (Storer, 1991; Douglas, 1992; Fersht \& Winter, 1992; Amold, 1993; Hedstrom, 1994). However, one of the major promises of this technology, the engineering of new catalytic activities in novel or existing proteins, has not been fulfilled with as much success. The catalytic mechanisms of a number of enzyme-catalyzed reactions have been studied by protein engineering (Fersht \& Winter, 1992; Phillips \& Fletterick, 1992; Gerlt, 1994), but despite the enormous progress made in understanding enzyme mechanisms, the nature of the modifications needed to alter catalytic activity or to introduce new activity into an enzyme remains elusive. For this reason,

'NRCC Publication Number 38556.

* Author to whom correspondence should be addressed.

É. Dufour is a visiting scientist from Institut National de la Recherche Agronomique, BP 1627, 44316 Nantes Cedex 03, France.

\& Abstract published in Advance ACS Abstracts, November 15, 1995. it has been suggested that a better strategy for developing a novel catalyst might be to first select an enzyme with the desired catalytic activity and tailor its substrate binding properties to a given substrate instead of trying to adapt binding sites for catalysis (Hedstrom. 1994). However, the enormous diversity of the binding sites of antibodies has been exploited for the production of new proteins with respectable levels of catalytic activity (Jacobs, 1991; Hilvert, 1994). The three-dimensional structure of a hydrolytic antibody (Zhou et al., 1994) clearly shows structural convergence between the active site of the catalytic antibody and of serine proteases, indicating that this approach is capable of generating a precise catalytic machinery similar to that resulting from millions of years of protein evolution.

Protein engineering of a known enzyme is also a valid approach for developing novel catalysts, which might prove to be advantageous over the previously mentioned methods in cases in which, for example, an enzyme is needed that requires extended substrate binding sites. However, there are only a few reports where this approach has been successful. Possibly the best example of rational design of a novel catalyst from an existing enzyme is subtiligase, an enzyme resulting from the efforts of Wells and co-workers at Genentech to engineer subtilisin for ligation of peptide bonds in solution (Abrahmsén et al., 1991; Jackson et al., 1994). The usefulness of this enzyme has been demonstrated by the blockwise synthesis of fully active ribonuclease A-containing unnatural amino acids (Jackson et al., 1994). Redesigning catalytic properties of an enzyme in a predictive manner requires extensive knowledge of the structural details of the enzyme and of its complexes with various ligands. and analogs of reaction intermediates. This is the case for the serine protease subtilisin, the precursor of subtiligase. In the cysteine protease class of enzymes, papain is a good example of a relatively well-defined system. Papain has been 


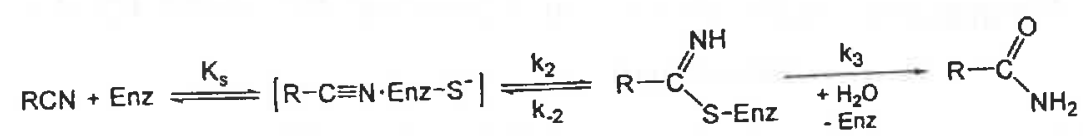

\section{Amidase Activity}

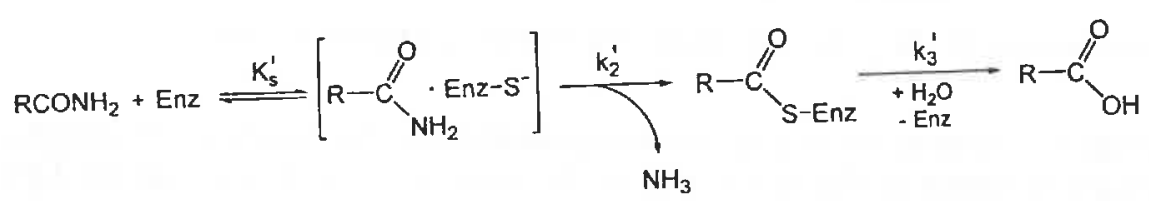

FIGURE 1: General mechanism and kinetic parameters for the nitrile hydratase and amidase activities of papain. $K_{\mathrm{s}}$ and $K_{\mathrm{s}}^{\prime}$ represent the

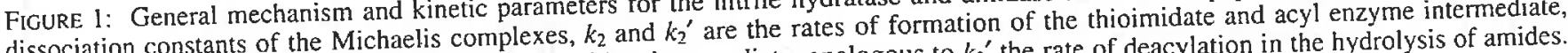
and $k_{3}$ represents the rate of hydrolysis of the thioimidate intermediate, analogous to $k_{3}$ the rate of deacylation in the hydrolysis of amides. an $k_{3}$ in the nitrile hydratase activity, formation of the thioimidate is reversible, with $k_{-2}$ as the rate constant for the reverse reaction.

extensively characterized (Baker \& Drenth, 1987; Brocklehurst et al., 1987), and three-dimensional structures are available for the free enzyme as well as a number of enzyme-inhibitor complexes (Drenth et al., 1976; Kamphuis et al., 1984; Schröder et al., 1993). In addition, the catalytic mechanism, substrate specificity, and inhibition of papain have been investigated by site-directed mutagenesis [e.g., Khouri et al. (1991), Ménard et al. (1990, 1991a-c, 1995), Dufour et al. (1995), and Vernet et al. (1995)]. We have decided to exploit our understanding of the relationship between structure and function in cysteine proteases by attempting to engineer an efficient nitrile hydratase activity into papain (Figure 1). Due to the natural amidase activity of papain, the amide generated through hydrolysis of the nitrile would then be further hydrolyzed to the corresponding acid.

\section{MATERIALS AND METHODS}

The papain mutants Gln19Glu, Gln19His, and Gln19Ala were prepared as described elsewhere (Ménard et al., 1991c, 1995). The mutants were expressed in insect cells infected with recombinant baculoviruses (Vernet et al., 1990). The secreted papain precursors were activated in vitro and then purified (Ménard et al., 1991b). Papain was obtained as the crystallized suspension in sodium acetate from Sigma Chemical Co. and was further purified and activated, and the active site was titrated as described previously (Ménard et al., 1990). The peptide nitriles MeOCO-PheAla-CN, $\mathrm{MeOCO}$-(L)PheGly-CN, and MeOCO-(D)Phe-Gly-CN were synthesized as described previously (Lowe \& Yuthavong, 1971; Storer et al., 1982). The amide substrates MeOCO(L)PheGly-NH $\mathrm{NH}_{2}$ and MeOCO-(D)PheGly- $\mathrm{NH}_{2}$ were prepared by hydrolysis of the corresponding peptide nitriles by $2-\mathrm{ME}$ [ 1 month of incubation of the peptide nitrile $(4 \mathrm{mM})$ with $20 \mathrm{mM}$ 2-ME, ph 7, $\left.25^{\circ} \mathrm{C}\right]$. The resulting amides were purified by reverse phase HPLC on a C-18 column (Vydac). CBZ-PheAla- $\mathrm{NH}_{2}$ was purchased from Bachem BioScience

1 Abbreviations: 2-ME, 2-mercaptoethanol; MeOCO-PheAla-CN, methoxycarbonyl-L-(phenylalanyl)-L-alanine nitrile; MeOCO-PheGly$\mathrm{CN}$ methoxycarbonyl-L-(phenylalanyl)aminoacetonitrile; $\mathrm{MeOCO}$ PheGly-NH, methoxycarbonyl-L-(phenylalanyl)glycine amide; CBZ( PheAla-NH2, carbobenzoxy-L-(phenylalanyl)-L-arginine 4-methylPheArg-MCA, carbobenzoxy-L-(phenylalanyl)-L-arginine 4-methylcoumarinyl-7-amide; Ac-PheGly-PNA, $N$-acetyl-L-(phenylalanyl)glycine 4-nitroanilide; E-64, 1-[(L-trans-epoxysuccinyl)-L-leucyl]amino4-guanidinobutane. All amino acids were (L) unless otherwise specified.
Inc. The substrate CBZ-PheArg-MCA was purchased from IAF Biochem International Inc., Laval, Québec. The irreversible inhibitor E-64 was obtained from IAF Biochem International Inc., and 2-ME was purchased from Aldrich.

Kinetic Measurements. The rate of hydrolysis of the nitrile was measured by using analytical HPLC to monitor the decrease in peptide nitrile concentration with time. The reaction conditions consisted of $1 \mathrm{mM} \mathrm{MeOCO}-\mathrm{PheAla}-\mathrm{CN}$, $50 \mathrm{mM}$ citrate buffer $\mathrm{pH} 5.0,0.2 \mathrm{M} \mathrm{NaCl}, 1 \mathrm{mM}$ EDTA, $10 \% \mathrm{CH}_{3} \mathrm{CN}, 22{ }^{\circ} \mathrm{C}$. Aliquots were taken at various time intervals and quenched by addition of $5 \mu \mathrm{L}$ of $50 \mu \mathrm{M}$ E-64 (for reaction with Gln 19Glu) or $10 \mu \mathrm{L}$ of $100 \mathrm{mM} \mathrm{E}-64$ (for wild type papain). Samples were analyzed on a reverse phase C-18 column (Vydac) using a Waters HPLC system. The absorbance was recorded at $214 \mathrm{~nm}$. Fractionation of nitrile, amide, and acid compounds was carried out with a linear gradient from $0 \% \mathrm{CH}_{3} \mathrm{CN}\left(0.11 \%\right.$ TFA) to $38 \% \mathrm{CH}_{3} \mathrm{CN}$ $(0.1 \% \mathrm{TFA})$ in $30 \mathrm{~min}$ at a flow rate of $1 \mathrm{~mL} / \mathrm{min}$. All peaks were identified by injection of the pure compounds. The concentrations of the compounds were determined by peak integration. MeOCO-PheAla-CN solutions of known concentrations were used as HPLC standards. The rate of peptide nitrile hydrolysis was found to be independent of substrate concentrations between 0.5 and $3 \mathrm{mM}$, indicating enzyme saturation and measurement of the initial rate can be used to obtain $k_{\text {cat }}$. The value of $K_{\mathrm{M}}$ was obtained by determining the $K_{\mathrm{i}}$ for inhibition of CBZ-PheArg-MCA hydrolysis by the nitrile, as described previously (Dufour et al., 1995). It must be noted that $K_{\mathrm{M}}$ (or $K_{\mathrm{i}}$ ) does not vary with concentration of $2-\mathrm{ME}$ at the concentrations used in this study (Dufour et al., 1995). For the $\mathrm{pH}$-dependency of the nitrile hydratase activity, the experimental conditions were the same as above, except that citrate buffer was replaced by $50 \mathrm{mM}$ phosphate for experiments at $\mathrm{pH} 7.00$. and 7.96 and MeOCO-PheGly-CN was used as the substrate. The $\mathrm{pH}$-activity profile was analyzed according to a model in which only one residue is considered to modulate activity. The corresponding equation is:

$$
\left(k_{\mathrm{cat}} / K_{\mathrm{M}}\right)=\frac{\left(k_{\mathrm{cat}} / K_{\mathrm{M}}\right)^{\mathrm{lim}}}{1+\left(K_{\mathrm{a}} /\left[\mathrm{H}^{+}\right]\right)}
$$

where $K_{\mathrm{i}}$ is the ionization constant of the group modulating activity and $\left(k_{\text {cal }} / K_{\mathrm{M}}\right)^{\mathrm{lim}}$ is the limiting value of the specificity constant. Nonlinear regression of the $\mathrm{pH}$-activity data was 
done using the program ENZFITTER written by R. J. Leatherbarrow (EIsevier-Biosoft).

The amidase activity was measured by monitoring the release of ammonia using a fluorescent assay based on the reaction with $o$-phthaldialdehyde and 2-ME (Taylor et al., 1974). Aliquots of $100 \mu \mathrm{L}$ from the reaction mixture were quenched with E-64 at various time intervals and incubated with $o$-phthaldialdehyde $(37.5 \mathrm{mM})$ and $2-\mathrm{ME}(3.6 \mathrm{mM})$ in a $0.2 \mathrm{M}$ phosphate buffer, $\mathrm{pH} 7.4$, for $45 \mathrm{~min}$. Fluorescence was then measured at $472 \mathrm{~nm}$ (excitation: $410 \mathrm{~nm}$ ). The standard curve for the assay was established using ammonium sulfate solutions $(0-2 \mu \mathrm{M})$. Reaction conditions are the same as those used for the nitrile hydratase activity. Initial rates were measured at various substrate concentrations ranging from 0.05 to $0.50 \mathrm{mM}$ (with wild type papain) or $0.40 \mathrm{mM}$ (with Gln19Glu). The graph of initial rate vs substrate concentration is linear for both substrates (indicating that $[\mathrm{S}] \ll K_{\mathrm{M}}$ ), and $k_{\mathrm{cat}} / K_{\mathrm{M}}$ was obtained by dividing the slope of this graph by the enzyme concentration.

\section{RESULTS AND DISCUSSION}

Binding of Peptide Nitriles to Papain and Strategy for Mutant Design. The complexity of designing a protein with novel catalytic activity requires that a systematic knowledgebased approach be used. Peptide nitriles are reversible inhibitors of cysteine proteases as they react with the active site cysteine to form covalent thioimidates (Lucas \& Williams, 1969; Brisson et al., 1986; Moon et al., 1986; Liang \& Abeles, 1987). Even though this complex could conceivably undergo hydrolysis, experiments have suggested that hydrolysis does not occur (Sluyterman \& Wijdenes, 1973; Lewis \& Wolfenden, 1977; Liang \& Abeles, 1987) and that the reverse reaction regenerating the nitrile and free enzyme is favored. Our group has previously reported the hydrolysis of the thioimidate to yield the corresponding amide (GourSalin et al., 1991), but the enzyme is extremely inefficient and a significant degree of reaction requires very high enzyme concentrations and the presence of 2-ME. The thioimidate at the active site of papain has been shown to exist in the nonprotonated form (Gour-Salin et al., 1991). Since the hydrolysis of thioimidates in solution is acidcatalyzed (Chaturvedi et al., 1967), the reaction between papain and a peptide nitrile could be altered to favor hydrolysis of the thioimidate intermediate by introducing an acid residue that could act as a proton donor to the thioimidate. However, since enzymes require a very high degree of precision in the geometry of their active site, the localization of this residue is a crucial factor in the design process.

The structure of the thioimidate complex resembles that of the acyl enzyme intermediate in the reaction pathway for substrate hydrolysis. By analogy with the three-dimensional structures of a number of papain-inhibitor complexes that represent models for the acyl enzyme (Drenth et al., 1976), the nitrogen atom of the thioimidate might be directed toward a region of the enzyme termed the "oxyanion hole." This region is defined by two hydrogen bond donors located on the backbone amide nitrogen of Cys 25 and the side chain amide of $G \ln 19$ (Drenth et al., 1976) and has been shown to constitute part of the catalytic machinery of cysteine proteases (Ménard et al., 1991c, 1995). Recent site-directed mutagenesis experiments strongly support the suggestion that
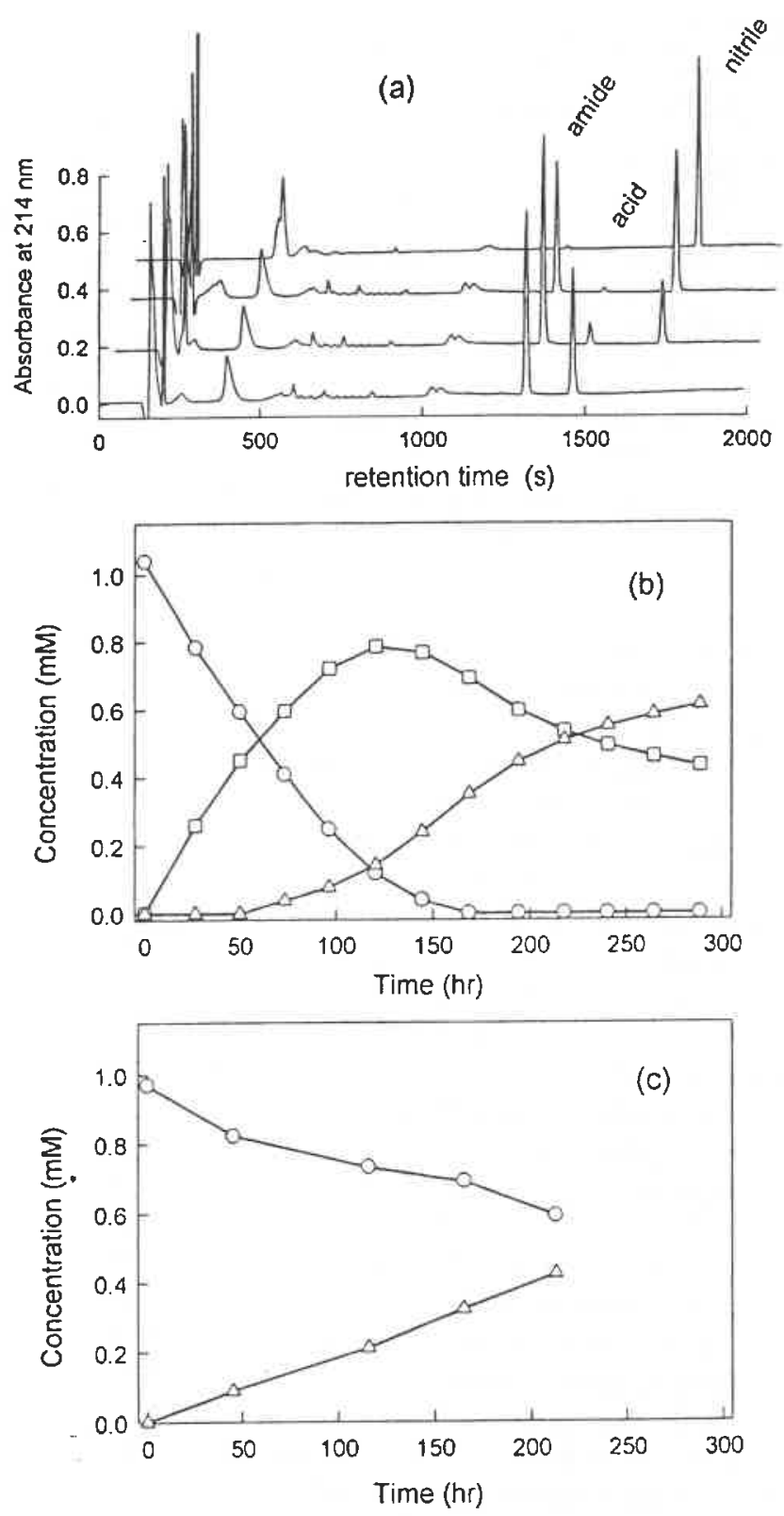

FIGURE 2: (a) Analytical HPLC of the products generated during hydrolysis of the peptide nitrile MeOCO-PheAla-CN by the GIn 19Glu mutant. Aliquots were taken at intervals between 0 and 194 h. 1, peptide nitrile alone, $t=0 ; 2,50 \mathrm{~h} ; 3,96.5 \mathrm{~h} ; 4,194 \mathrm{~h}$. (b) Time course for the reaction with GIn19Glu mutant ( $30 \mathrm{nM}$ ): $O$, nitrile; $\square$, amide; $\Delta$, acid. (c) Same as b, except that $205 \mu \mathrm{M}$ wild type papain and $10 \mathrm{mM} 2-\mathrm{ME}$ were used.

thioimidates formed between papain and peptide nitriles interact in the oxyanion hole of the enzyme (Dufour et al., 1995). Mutations of Gln 19 in papain were shown to decrease binding affinity for the peptide nitrile MeOCO-PheGly-CN. In addition, the inhibitory activity of the nitrile has been shown to be modulated by ionization of a glutamic acid introduced at position 19 in papain. Therefore, the oxyanion hole might be a proper region for the introduction of an acid residue. On the basis of these results, mutants in which residue $\mathrm{G} \ln 19$ has been replaced by Glu or His have been prepared and assayed for nitrile hydratase activity.

Nitrile Hydratase Activity of a Gln19Glu Mutant of Papain. The activity of three oxyanion hole mutants of papain, GIn 19Glu, Gln19His, and Gln 19Ala, and of wild type papain against the substrate MeOCO-PheAla-CN was monitored by analytical HPLC. As shown in Figure 2a. three 
Table 1: Kinetic Parameters for the Nitrile Hydratase and Amidase Activities of Wild Type and Gln $19 \mathrm{Glu}$ Papain at pH 5.0

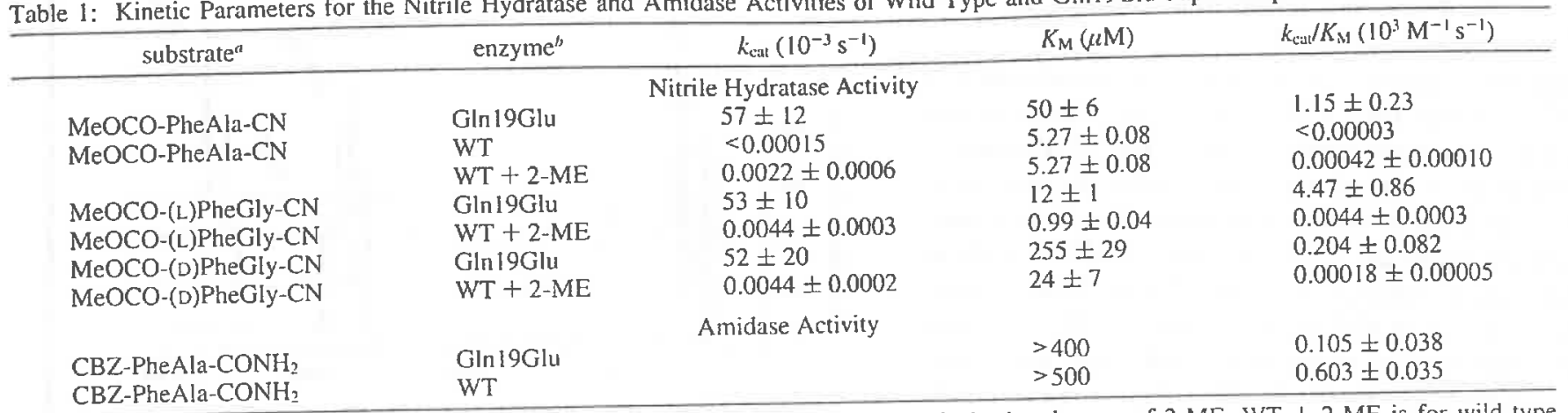

"All amino acids are (L) unless specified otherwise. "WT refers to wild type papain in the absence of 2-ME; WT + 2-ME is for wild type papain in the presence of $2.5 \mathrm{mM} 2-\mathrm{ME}$, except for the experiment with the substrate MeOCO-PheAla-CN, in which the 2-ME concentration was $10 \mathrm{mM}$.

species can be detected and are well resolved in the chromatogram: the starting substrate (nitrile) and the corresponding amide and acid products. HPLC offers a convenient method to follow both the nitrile hydratase and amidase activities of the enzymes. The time course of the reaction for the GIn $19 \mathrm{Glu}$ mutant at $\mathrm{pH} 5.0$ is reported in Figure 2b. Hydrolysis of the nitrile leads to accumulation of the corresponding amide, which is then further hydrolyzed to the acid (Figure 1). A lag phase is observed in the production of the acid, due to the stepwise reaction involving the formation of the amide as an intermediate. As expected, a lag phase is also observed for the release of ammonia (data not shown), monitored using a fluorescent assay based on the reaction of $o$-pthaldialdehyde with ammonia in presence of 2-ME (Taylor et al., 1974). The conversion of the amide to the acid is slow because of the presence of the nitrile, which acts as a competitive inhibitor for the amidase reaction. Both the nitrile hydratase and the amidase activities are inhibited by the cysteine protease inhibitor E-64. Comparison with wild type papain (Figure 2 c) clearly shows that the reaction with the mutant is much faster. The half-life of the nitrile is similar in both cases, even though the concentration of Gln 19Glu is approximatively 7000 -fold lower than that of wild type papain. It must be noted, however, that the reaction with wild type enzyme but not the mutant was monitored in presence of $10 \mathrm{mM} 2-\mathrm{ME}$ and that no activity could be detected in absence of 2-ME. The role of 2-ME is probably to act as a nucleophile attacking the thioimidate to generate the amide product (Gour-Salin et al., 1991). 2-ME has also been reported to hydrolyze nitriles to amides at neutral pH in solution (Zervos \& Cordes, 1971; Lee et al., 1989), probably through formation of a chelate involving both functional groups of 2-ME. However, control experiments showed that 2-ME alone did not hydrolyze the nitrile substrate at pH 5.0. Hydrolysis of the nitrile to the amide by $2-\mathrm{ME}$ could be detected at $\mathrm{pH} 7.0$, but the reaction was extremely slow. The difference in activity between GIn19Glu and wild type papain is therefore greater than what is shown in Figure 2. Contrary to the reaction with Gin19Glu, no amide product is seen to accumulate with the wild type, indicating that the nitrile hydratase activity is rate-limiting in this case. For Gln19Glu, the nitrile hydratase activity is greatly accelerated and the amidase activity becomes ratelimiting. In addition, no nitrile hydratase activity was detected for mutant Gln19His or Gin19Ala at enzyme concentrations similar to Gln19Glu.
From the results reported in Figure 2, kinetic parameters can be extracted to describe the nitrile hydratase activity. In the mechanism shown in Figure 1, the step for conversion of the thioimidate to the amide is slow as compared to the rate of formation of the thioimidate, which is known to be rapid (Liang \& Abeles, 1987; Dufour et al., 1995). Under this condition, it can be shown that for the nitrile hydratase reaction $k_{\mathrm{cat}}=k_{3}$ and $K_{\mathrm{M}}$ is the dissociation constant of the thioimidate adduct, which corresponds to the $K_{\mathrm{i}}$ for inhibition of substrate hydrolysis under conditions where the nitrile hydratase activity can be considered to be nonsignificant. The results are reported in Table 1. For wild type papain in the absence of 2-ME, the limit of detection of the HPLC assay was used to set upper limits to $k_{\text {cat }}$ and $k_{\text {cal }} / K_{\mathrm{M}}$. It can be seen that at $\mathrm{pH} \mathrm{5.0,} \mathrm{the} \mathrm{introduction} \mathrm{of} \mathrm{a} \mathrm{glutamic} \mathrm{acid}$ residue in the oxyanion hole of papain causes the $k_{\text {eat }}$ for the nitrile hydratase reaction to increase by a factor equal to or greater than $4 \times 10^{5}$. The mutation also causes the $K_{\mathrm{M}}$ to increase 10 -fold, indicating a decrease in the stability of the thioimidate adduct as previously reported (Dufour et al., 1995). The $k_{\text {cau }} / K_{\mathrm{M}}$ value for nitrile hydratase activity of Gin 19Glu is therefore at least $4 \times 10^{4}$-fold higher than that of wild type papain. If the results are compared with wild type enzyme in presence of $10 \mathrm{mM} 2-\mathrm{ME}$, then the increases in rate are $2.6 \times 10^{4}$ and $2.7 \times 10^{3}$ for $k_{\text {cat }}$ and $k_{\text {cat }} / K_{\mathrm{M}}$, respectively.

Figure 3 shows the $\mathrm{pH}$-dependency of the nitrile hydratase reaction of Gln 19Glu against the substrate MeOCO-PheGly$\mathrm{CN}$. Activity is greater at acidic $\mathrm{pH}$, and the transition observed in the $\mathrm{pH}$-dependency curve can be described by the ionization of a single group on the enzyme with a $\mathrm{p} K_{\mathrm{a}}$ of 6.03 . This value is in agreement with the $\mathrm{p} K_{\mathrm{a}}$ found previously for the glutamic acid side chain introduced at position 19 in the Gln19Glu mutant (Ménard et al., 1995) and confirms the involvement of the acid form of the Glu19 residue in the nitrile hydratase reaction. As expected, mutation of the Gln 19 residue causes the amidase activity of the enzyme to decrease (Table 1). The $k_{\text {cal }} / K_{\mathrm{M}}$ for conversion of the amide substrate CBZ-PheAla- $\mathrm{NH}_{2}$ to the corresponding acid by Gln19Glu at pH 5.0 is $105 \mathrm{M}^{-1} \mathrm{~s}^{-1}$, a value 6 -fold lower than with wild type papain. By comparison, the activity of Gin19Glu against CBZ-PheArg-MCA at pH 5.0 was found to be 20 -fold lower than with the wild type enzyme (Ménard et al., 1995). As noted previously, among a collection of oxyanion hole mutants characterized, the Gin 19Glu mutant, in which the glutamic acid side chain 


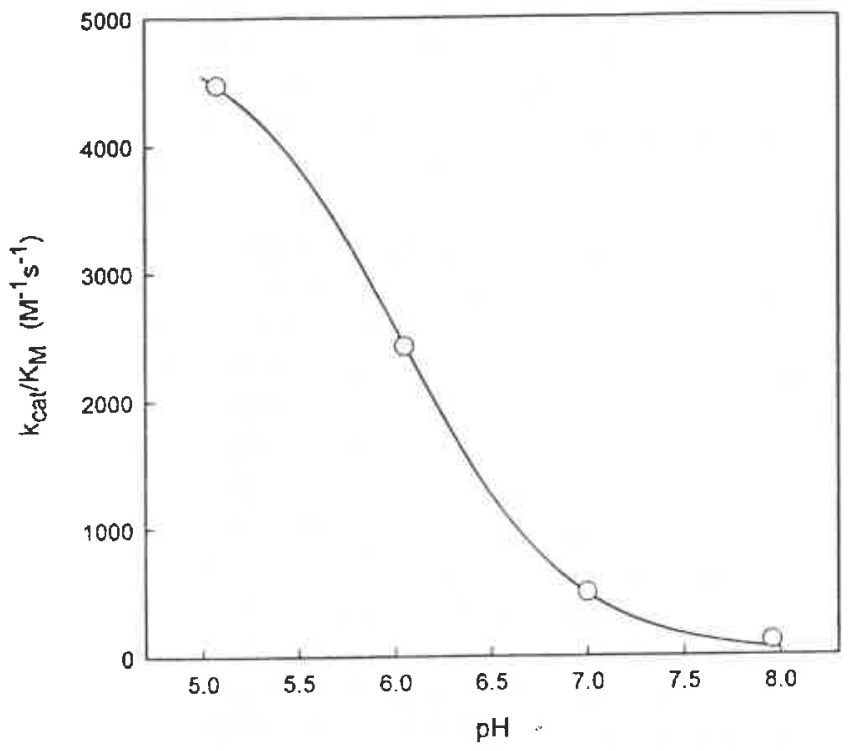

FiguRE 3: pH-dependence of the nitrile hydratase activity. MeOCOPheGly- $\mathrm{CN}$ was used as the substrate. The $\mathrm{pH}$-activity profile was analyzed according to a model in which only one residue is considered to modulate activity. The solid line represents the best fit of the data to the model, corresponding to $\mathrm{p} K_{\mathrm{il}}=6.03 \pm 0.02$ and $\left(k_{\mathrm{cal}} / K_{\mathrm{M}}\right)^{\mathrm{lim}}=4.97 \pm 0.06 \times 10^{3} \mathrm{M}^{-1} \mathrm{~s}^{-1}$.

is nonionized, is the mutant that displays the closest activity to wild type papain.

Specificity and Stereoselectivity of the Nitrile Hydratase Activity. Specificity in cysteine protease-catalyzed substrate hydrolysis is reflected almost entirely in the acylation step ( $k_{2}{ }^{\prime}$ in Figure 1) (Lowe \& Yuthavong, 1971). Interaction in the $S_{2}$ subsite fusing the nomenclature of Schechter and Berger (1967)] is the predominant factor defining substrate specificity in papain (Baker \& Drenth, 1987; Brocklehurst et al., 1987), and it has been proposed that $S_{2}$ subsite interactions were coupled to the nature of active site chemistry (Kowlessur et al., 1990). In particular, stereose- lectivity of the $\mathrm{P}_{2}$ residue has been proposed to be linked to conformational constraints at the active site involving acidcatalyzed expulsion of the leaving group by His 159 in the acylation step. The effect of the $\mathrm{P}_{2}$ chirality on the effectiveness of the nitrile hydratase activity with wild type and Gln 19Glu papain is presented in Table 1. For the peptide nitrile MeOCO-PheGly-CN, the (L)Phe isomer is preferred over (D)Phe by a factor of 19 with the mutant Gln 19Glu. A similar ratio of 25 is obtained with wild type papain even though the activity is much lower. By comparison, (L)Phe is favored over (D)Phe in the $P_{2}$ position of the substrates Ac-PheGly-PNA and CBZ-PheArg-MCA by factors of 330 and 135, respectively (Kowlessur et al., 1990; Gour-Salin et al., 1994). This difference could be attributed to the absence of a leaving group in nitrile hydrolysis leading to less stringent conformational demands in the geometry of reaction intermediates at the active site. However, (L)Phe is preferred over (D)Phe in the amide substrate MeOCOPheGly- $\mathrm{NH}_{2}$ by a factor of only 27 (data not shown) despite the requirement for protonation of the leaving group with this substrate. Therefore, stereoselectivity at position $P_{2}$ of a substrate might not be linked to conformational constraints dictated by the active site histidine residue His 159. Alternatively, this result could be used to imply that protonation of the nitrogen atom of the nitrile group during formation of the thioimidate intermediate is assisted by His 159. It can be seen also in Table 1 that the specificity of the nitrile hydratase activity is expressed in the formation of the thioimidate intermediate, since $k_{\text {car }}$ (i.e., $k_{3}$ ) is the same for two peptide nitriles with $k_{\mathrm{cat}} / K_{\mathrm{M}}$ values different by a factor of approximately 20 .

Mechanism of the Papain Nitrile Hydratase. The mechanism of the nitrile hydratase activity in papain is represented in Figure 4. The reaction involves the formation of a thioimidate intermediate analogous to the acyl enzyme formed during hydrolysis of amides and esters. Attack of

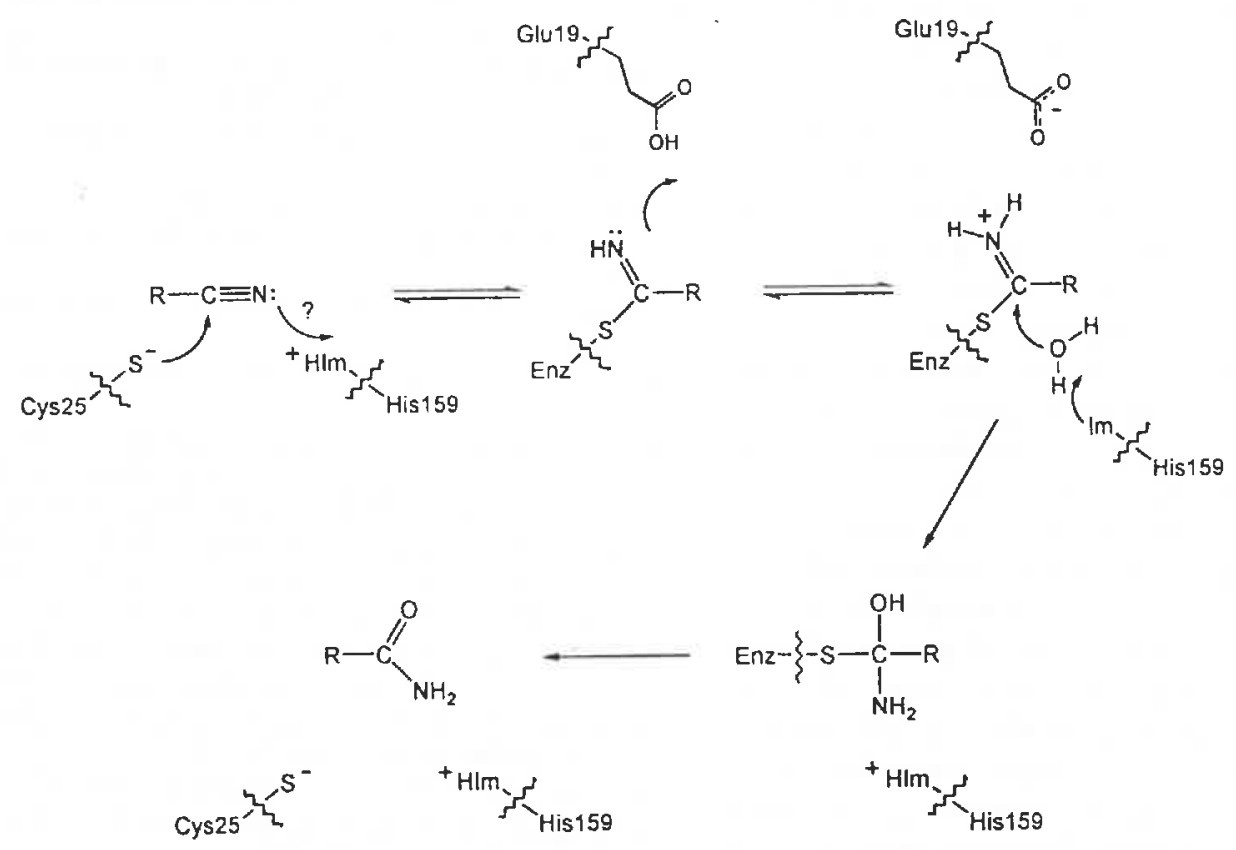

FiGURE 4: Schematic representation of the proposed mechanism for the nitrile hydratase activity of the Gln19Glu mutant. The first reversible step (formation of the thioimidate intermediate) might be assisted by His 159, as discussed in the text. Protonation of the thioimidate by Glu 19 activates the intermediate towards nucleophilic attack by a water molecule. Similarly to deacylation in the amidase reaction, this step is believed to be assisted by base catalysis from His 159 . The resulting tetrahedral complex then breaks down to the amide and the free enzyme. 
Engineering Nitrile Hydratase Activity

this intermediate by a water molecule yields the corresponding amide product. For thioimidates in solution, base catalysis has been shown to favor the reverse reaction leading to free thiol and nitrile (Chaturvedi et al., 1967). Since with papain deacylation is known to be base-catalyzed, the catalytic machinery of wild type papain can facilitate the base-catalyzed elimination of the nonprotonated thioimidate to the nitrile and free enzyme ( $k_{-2}$ in Figure 1$)$, which might explain why the nitrile hydratase activity is virtually nonexistent for the wild type enzyme. The role of the glutamic acid residue introduced at position 19 in the Gin19Glu enzyme is to participate in the acid-catalyzed hydrolysis of the thioimidate to the amide by the provision of a proton to form the more reactive protonated thioimidate (Figure 4). This dramatically decreases the energy barrier for the hydrolysis of the thioimidate, as shown by the impressive increase in $k_{\text {cat }}\left(k_{3}\right)$ by a factor of more than $4 \times 10^{5}$.

Nitrile-hydrolyzing enzymes are present in microorganisms that are able to use nitriles as a source of carbon and/or nitrogen. Two different enzymatic routes are known for the degradation of nitriles: nitrilases catalyze the direct cleavage of nitriles to yield the corresponding acid and ammonia, without generation of the amide, while nitrile hydratases catalyze the hydrolysis of a nitrile to the amide (Nagasawa \& Yamada, 1989; Kobayashi et al., 1992). Very little is known on the mechanism of nitrilases or nitrile hydratases. Even though both classes of enzymes act on nitriles, they use different catalytic reaction mechanisms. The active site of natural nitrile hydratases has been shown to contain a metal center and possibly a pyrroloquinoline quinone cofactor (Nagasawa \& Yamada, 1989; Kobayashi et al., 1992). Natural nitrilases, however, share a number of features with the papain nitrile hydratase. Nitrilases possess a catalytically essential cysteine residue and are proposed to function by a mechanism involving the formation of covalent thioimidate and acyl enzyme intermediates (Thimann \& Mahadevan, 1964; Harper, 1977; Stevenson et al., 1992). Even though we have termed our mutant a nitrile hydratase, it can be considered as a nitrilase since the amide formed from hydrolysis of the nitrile is subsequently hydrolyzed further to the acid. The difference between the papain mutant Gln19Glu and natural nitrilases is that for the latter, no amide is generated in the process. It must be noted, however, that formation of small amounts of amide can be detected with nitrilases when poor substrates are used, possibly due to anomalous breakdown of the reaction intermediate (Stevenson et al., 1992). The most interesting observation in our view comes from a recently published report indicating significant sequence conservation between a group of enzymes that are involved in nitrogen metabolism and that cleave nitriles and amides (Bork \& Koonin, 1994). The enzymes that form this group are nitrilases, cyanide hydratases, aliphatic amidases, and $\beta$-alanine synthase, and they are characterized by several conserved motifs. In one of the motifs, an invariant cysteine residue is found, and this is the same residue that has been found to be involved in the active site of nitrilases. An invariant glutamic acid residue is also found in a conserved motif near the $\mathrm{N}$-terminal region of the proteins, and it was suggested that it might also be a direct participant in the reactions. However, acid catalysis by this residue would require a relatively high $\mathrm{p} K_{\mathrm{a}}$ value for the Glu side chain, since many of these enzymes are active at neutral $\mathrm{pH}$. Our finding that an acid residue can dramatically increase the nitrile hydratase activity of papain supports this hypothesis and the proposal that the proteins used in the sequence aligments constitute a family of enzymes sharing a common catalytic mechanism.

The present work demonstrates that a peptide nitrile hydratase activity can be engineered into a cysteine protease by a single carefully selected mutation at the active site of the enzyme. The success of the rational approach undertaken is a consequence of the level of understanding of the basic catalytic properties of cysteine proteases of the papain family. Given the present unpredictability of the functional consequences of amino acid replacements, it is unlikely that protein engineering by itself can substitute for other methods to generate enzymes with novel activities. For the alteration of an enzyme that is not as well characterized, the use of random mutagenesis of the gene coding for the enzyme and phage display for the screening and selection of the desired activity offers an interesting alternative to the rational design approach (Clackson \& Wells, 1994; Soumillion et al., 1994). Both methods, however, can undoubtedly act in a synergistic manner to identify protein modifications needed to alter the catalytic activity of an enzyme.

\section{ACKNOWLEDGMENT}

We thank NATO and the Ministère de la recherche et de lespace (France) for postdoctoral support (E.D.).

\section{REFERENCES}

Abrahmsén, L.. Tom. J., Burnier, J., Butcher, K. A., Kossiakoff, A., \& Wells, J. A. (1991) Biochemistry 30, 4151-4159.

Arnold, F. H. (1993) Curr. Opin. Biotechnol. 4, 450-455.

Baker, E. N.. \& Drenth. J. (1987) in Biological Macromolecules and Assemblies, Volume 3: Active Sites of Enzymes (Jurnak. F. A., \& McPherson. A.. Eds.) pp 314-367, John Wiley \& Sons. New York.

Bork, P., \& Koonin. E. V. (1994) Protein Sci. 3, 1344-1346.

Brisson. J.-R., Carey. P. R., \& Storer, A. C. (1986) J. Biol. Chem. 261, 9087-9089.

Brocklehurst. K., Willenbrock, F., \& Salih, E. (1987) in Hydrolytic En-ymes (Neuberger. A., \& Brocklehurst, K., Eds.) pp 39-158, Elsevier, Amsterdam.

Charurvedi, R. K., MacMahon. A. E., \& Schmir, G. L. (1967) J. Am. Chem. Soc. 89, 6984-6993

Clackson, T., \& Wells. J. A. (1994) Trends Biotechnol. 12. 173184.

Douglas, K. T. (1992) Curr. Opin. Biotechnol. 3, 370-377.

Drenth, J., Kalk, K. H., \& Swen. H. M. (1976) Biochemistry 15, $3731-3738$.

Dufour, É., Storer, A. C.. \& Ménard, R. (1995) Biochemistry 34 , 9136-9143.

Fersht, A., \& Winter, G. (1992) Trends Biochem. Sci. 17, 292294.

Gerlt, J. A. (1994) Curr. Opin. Sinuct. Biol. 4, 593-597.

Gour-Salin, B. J., Storer, A. C., Castelhano, A., Krantz, A., \& Robinson. V. (1991) Enzyme Microbiol. Teclnol. 13, 408-411.

Gour-Salin, B. J., Lachance, P., Magny, M.-C., Plouffe, C., Ménard, R., \& Storer, A. C. (1994) Biochem. J. 299, 389-392.

Harper, D. B. (1977) Biochem. J. 165, 309-319.

Hedstrom, L. (1994) Curr. Opin. Struct. Biol. 4, 608-611

Hilvert, D. (1994) Curr. Opin. Struct. Biol. 4, 612-617.

Jackson, D. Y., Burnier, J., Quan, C., Stanley, M., Tom, J., \& Wells, J. A. (1994) Science 266, 243-247.

Jacobs, J. W. (1991) Biotechnology 9, 258-262.

Kamphuis, I. G., Kaik, K. H., Swarte, M. B. A., \& Drenth, J. (1984) J. Mol. Biol. 179, 233-256.

Khouri, H. E., Vernet, T., Ménard, R., Parlati, F., Laflamme, P., Tessier, D. C., Gour-Salin, B. J.. Thomas. D. Y.. \& Storer, A. C. (1991) Biochemistin 30, 8929-8936. 
Kobayashi, M., Nagasawa, T., \& Yamada, H. (1992) Trends Biotechnol. 10, 402-408.

Kowlessur, D., Thomas, E. W., Topham, C. M., Templeton, W., \& Brocklehurst, K. (1990) Biochem. J. 266, 653-660.

Lee, Y. B., Goo, Y. M., Lee, Y. Y., \& Lee, J. K. (1989) Tetrahedron Lett. $30,7439-7440$.

Lewis, C. A. Jr., \& Wolfenden, R. (1977) Biochemistry 16, 48904894.

Liang, T.-C., \& Abeles, R. H. (1987) Arch. Biochem. Biophys. 252, $626-634$

Lowe, G., \& Yuthavong, Y. (1971) Biochem. J. 124, 107-115.

Lucas, E. C., \& Williams, A. (1969) Biochemistry 8, 5125-5135.

Ménard, R., Khouri, H. E., Plouffe, C., Dupras, R., Ripoll, D., Vernet, T., Tessier, D. C., Laliberté, F., Thomas, D. Y., \& Storer, A. C. (1990) Biochemistry 29,6706-6713.

Ménard, R., Plouffe, C., Khouri, H. E., Dupras, R., Tessier, D. C. Vernet, T., Thomas, D. Y., \& Storer, A. C. (1991a) Protein Eng. 4, 307-311.

Ménard, R., Khouri, H. E., Plouffe, C., Laflamme, P., Dupras, R., Vernet, T., Tessier, D. C., Thomas, D. Y., \& Storer, A. C. (1991b) Biochemistry 30, 5531-5538.

Ménard, R., Carrière, J., Laflamme, P., Plouffe, C., Khouri, H. E. Vernet, T., Tessier, D. C., Thomas, D. Y., \& Storer, A. C. (199 Ic) Biochemistry 30, 8924-8928.

Ménard, R., Plouffe, C., Laflamme, P., Vernet, T., Tessier, D. C., Thomas, D. Y., \& Storer, A. C. (1995) Biochemistry 34, 464471.

Moon, J. B., Coleman, R. S., \& Hanzlik, R. P. (1986) J. Am. Chem. Soc. 108, 1350-1351.

Nagasawa, T., \& Yamada, H. (1989) Trends Biotechnol. 7, 153158.

Phillips, M. A., \& Fletterick, R. J. (1992) Curr. Opin. Struct. Biol. 2, 713-720.
Schechter, I., \& Berger, A. (1967) Biochem. Biophys. Res. Conumun. $27,157-162$.

Schröder, E., Phillips, C., Garmen, E., Harlos, K., \& Crawford, C. (1993) FEBS Lett. 315, 38-42.

Sluyterman, L. A. E., \& Wijdenes, J. (1973) Biochim. Biophys. Acta 302, 95-101.

Soumillion, P., Jespers, L., Bouchet, M., Marchand-Brynaert, J., Sartiaux, P., \& Fastrez, J. (1994) Appl. Biochem. Biotechnol. 47, $175-190$

Stevenson, D. E., Feng, R., Dumas, F., Groleau, D., Mihoc, A., \& Storer, A. C. (1992) Biotechnol. Appl. Biochen. 15, 283-302.

Storer, A. C., Ozaki, Y., \& Carey, P. R. (1982) Can. J. Chem. 60, 199-209.

Storer, A. C. (1991) Curr. Opin. Biotechnol. 2, 606-613.

Taylor, S., Ninjoor, V., Dowd, D. M., \& Tappel, A. L. (1974) Anal. Biochem. 60, 153-162.

Thimann, K. V., \& Mahadevan, S. (1964) Arch. Biochem. Bioplys. $105,133-141$.

Ulmer, K. M. (1983) Science 219, 666-671.

Vernet, T., Tessier, D. C., Richardson, C., Laliberté, F., Khouri, H. E., Bell, A. W., Storer, A. C., \& Thomas, D. Y. (1990) $J$. Biol. Chem. 265, 16661-16666.

Vernet, T., Tessier, D. C., Chatellier, J., Plouffe, C., Lee, T. S., Thomas, D. Y., Storer, A. C., \& Ménard, R. (1995) J. Biol. Chem. $270,16645-16652$.

Zervos, C., \& Cordes, E. H. (1971) J. Org. Chem. 36. 1661-1667.

Zhou, G. W., Guo, J., Huang, W., Fletterick, R. J., \& Scanlan, T. S. (1994) Science 265, 1059-1064.

B1951878J 
